\title{
Origin(s) of Antarctica's Wilkes Subglacial Basin
}

\author{
JOHN G. WEIHAUPT ${ }^{1}$, FRANS G. VAN DER HOEVEN ${ }^{2}$, CLAUDE LORIUS $^{3}$ and \\ FREDERICK B. CHAMBERS ${ }^{4}$ \\ ${ }^{I}$ Department of Geology, University of Colorado Denver, Denver, CO, USA \\ ${ }^{2}$ Department of Geophysics, Delft University of Technology, Delft, The Netherlands \\ ${ }^{3}$ Laboratoire de Glaciologie et Géophysique de l'Environnement, Grenoble, France \\ ${ }^{4}$ Department of Geography and Environmental Sciences, University of Colorado Denver, Denver, CO, USA \\ john.weihaupt@ucdenver.edu
}

\begin{abstract}
The Wilkes Subglacial Basin (WSB), the largest subglacial basin in East Antarctica, is a topographic depression of continental proportions that lies beneath the East Antarctic continental ice sheet. Discovered by the US Victoria Land Traverse 1959-60, the origin of the WSB and the influence of palaeoclimate on its overlying continental ice sheet have remained uncertain since the time of its discovery. Most explanations of origin favour lithospheric structural control as a function of tectonic activity. Lithospheric flexure due to thermally or isostatically induced uplift of the Transantarctic Mountains was suggested in the 1980s. Lithospheric extension and rifting was proposed in the 1990s. More recent investigations have revealed the presence of fold and thrust belts, casting doubt on flexural and extensional hypotheses as the primary mechanisms, suggesting instead a compressional scenario. While remaining inconclusive, these tectonic mechanisms in one form or another, or in combination, are now believed to have provided the structural control for the origin of the WSB. Not yet comprehensively examined, however, is the role of non-tectonic processes in the formation of the WSB, as they may have influenced the size, configuration, subglacial sedimentation and subglacial topography of the WSB. In this paper we review the tectonic hypotheses and examine post-tectonic climate change along with glacial and marine processes as potentially significant factors in the present condition and configuration of the WSB. In the process, we find that there are a number of features not included in previous investigations that may have been major factors in the modification of the subglacial basin.
\end{abstract}

Received 3 June 2013, accepted 24 August 2013

Key words: climate, continental ice sheet, lithosphere, subglacial topography

\section{Introduction}

Several discoveries made in 1959-60 by the US Victoria Land Traverse (VLT) as part of the US Antarctic Research Program included the earliest significant recognition of contemporary global warming, and our consequent awareness of the 'Anthropocene' (Lorius et al. 1979, Lorius et al. 1990). The VLT also discovered the Wilkes Land gravity anomaly, the Outback Nunataks, the USARP Mountains, the upper reaches of the Rennick Glacier, and the Wilkes Subglacial Basin (WSB) (Weihaupt 1961, Weihaupt et al. 2012). These features were named by the Advisory Committee on Antarctic Names (US-ACAN) in 1961 upon completion of the VLT. The WSB, an extensive lowland beneath the East Antarctic continental ice sheet, extends from its southern end in the vicinity of $82^{\circ} 00^{\prime} \mathrm{S}$, $140^{\circ} 00^{\prime} \mathrm{E}$, where it is approximately $20 \mathrm{~km}$ wide, northward to $67^{\circ} 00^{\prime} \mathrm{S}$, some $1400 \mathrm{~km}$ to the Southern Ocean on George V Coast. Here the WSB is approximately $900 \mathrm{~km}$ wide between longitudes $136^{\circ} 00^{\prime} \mathrm{E}$ and $158^{\circ} 00^{\prime} \mathrm{E}$, narrowing to its southern end and defining a triangular subglacial topographic feature that averages $400 \mathrm{~km}$ in width (Fig. 1).
Since its discovery, interest has been heightened in the relationships between the WSB, the Transantarctic Mountains (TAM) and the Ross Sea rift (RSR). The WSB in particular has been the subject of numerous investigations because of its enigmatic character (Armadillo et al. 2007, Ferraccioli et al. 2009, Jordan et al. 2013). Inconsistency between gravity modelling, observed gravity, sedimentary basement geometry in the RSR basin, and their departure from traditional oceanic or continental crust (Karner et al. 2005), has led to interest in the continental complex of the WSB, TAM and RSR, and descriptions of the RSR and contiguous regions as 'paradoxical' (Karner et al. 2005). Stimulated by the International Polar Year 2007-08, several investigators have further described the WSB as poorly understood (Armadillo et al. 2007), giving rise to differing explanations for its origin. These explanations have focused on the morphology and geology of the basin, possible thermal and isostatic uplift, craton margin rifting, magmatism, crustal architecture, buried fault patterns, magnetic lithospheric lineaments, sedimentary basins and subglacial lakes. Not significantly included in these investigations are non-tectonic features and processes, 


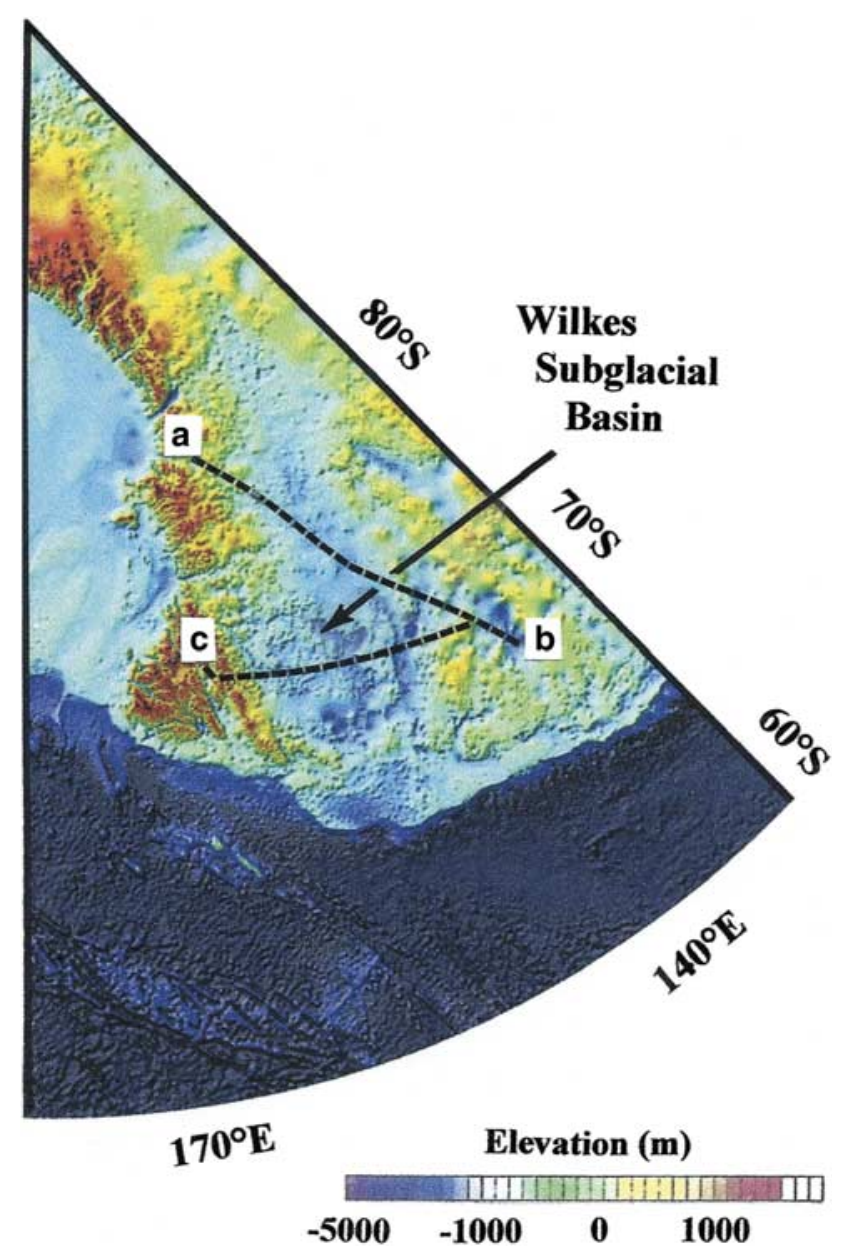

Fig. 1. BEDMAP2 map showing the Victoria Land Traverse route from a. the head of the Skelton Glacier at $78^{\circ} 00.0^{\prime} \mathrm{S}$, $154^{\circ} 02.0^{\prime} \mathrm{E}$, north-westward across the Victoria Land Plateau to b. $71^{\circ} 07.8^{\prime} \mathrm{S}, 139^{\circ} 11.0^{\prime} \mathrm{E}$, and eastward to c. the Transantarctic Mountains at $72^{\circ} 15.1^{\prime} \mathrm{S}, 160^{\circ} 08.0^{\prime} \mathrm{E}$ (Weihaupt 1961, Weihaupt et al. 2012, Fretwell et al. 2013).

such as the climatic history of East Antarctica, alternating glacial and interglacial episodes, ice sheet modelling and dynamics, glacial erosion, basin deposition, marine processes, sea level change and related landscape modelling.

The scientific importance of the WSB lies in the fact that its origin, structure and subsequent history may have implications for the origin, structure and history of the TAM, the RSR, the Gamburtsev Subglacial Mountains and the East Antarctic craton, and also the palaeoclimatic and glaciological history of Antarctica.

\section{Geologic and geographic setting of the Wilkes Subglacial Basin}

Magmatism occurred in the Jurassic period, and separation of East Antarctica from Australia began in the Cretaceous with complete separation occurring in the Oligocene. a

VICTORIA LAND PLATEAU

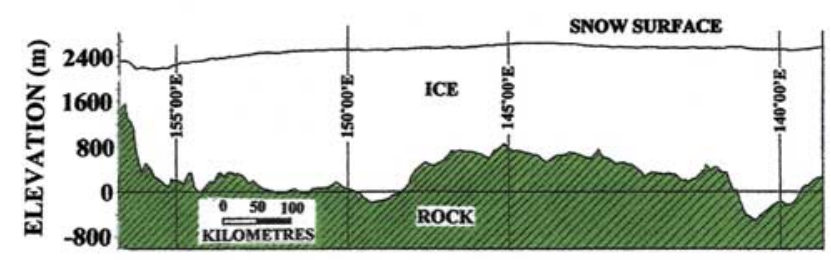

b

VICTORIA LAND PLATEAU

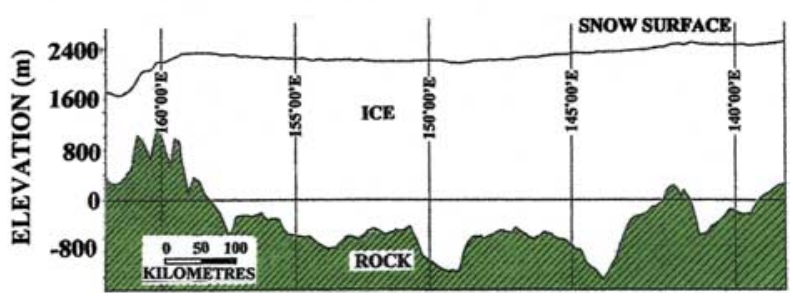

Fig. 2. Seismic-gravity profiles of the a. south leg and b. north leg of the Victoria Land Traverse (see Fig. 1) depicting the subglacial topography and the decrease in elevation of Wilkes Subglacial Basin from inland north toward the Southern Ocean (Weihaupt 1961, Weihaupt et al. 2012).

Uplift and formation of the TAM occurred in late Cretaceous, and large scale RSR sedimentation occurred in late Eocene-Neogene from denudation of the TAM, followed by Neogene volcanic activity (Karner et al. 2005). Whereas the ages of many of the lithospheric features in the WSB proper are not known because of the overlying continental ice sheet, geophysical investigations reveal aeromagnetic lineaments, aeromagnetic buried fault patterns, rifting, back-arc structures, sedimentary basins, subglacial lakes, water-saturated sediments and subglacial topographic features. Seismic and gravity surveys (Weihaupt et al. 2012) revealed the subglacial topographic structure of the WSB for the first time (Fig. 2). These profiles, when referred to one another, showed a continental scale basin that slopes from near the South Pole northward to the coast of the Southern Ocean.

Although comparatively few geophysical investigations were conducted in the region of the WSB in the period 1960-2000, recent aerial surveys confirm the seismic and gravity findings of 1959-60, and the topography and dimensions of the basin (Fig. 3). These surveys include airborne radio echo-sounding of subglacial topography (Fretwell et al. 2013) and airborne geophysical surveys revealing sub-ice geology (ten Brink et al. 1997, Studinger et al. 2004). Aeromagnetic surveys, providing valuable information about subglacial topography and crustal structure, reveal magnetic anomalies in the WSB lithosphere (Studinger et al. 2004), faulting along the margins of the WSB (Armadillo et al. 2007), deep and shallow geophysical structures (Armadillo et al. 2007), and subglacial structural lineaments (Ferraccioli et al. 2009). Of special interest is the BEDMAP work of Lythe et al. (2001) delineating the 
a

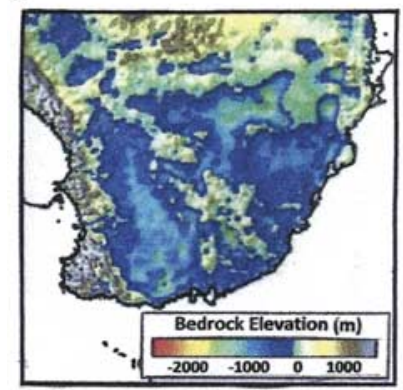

b

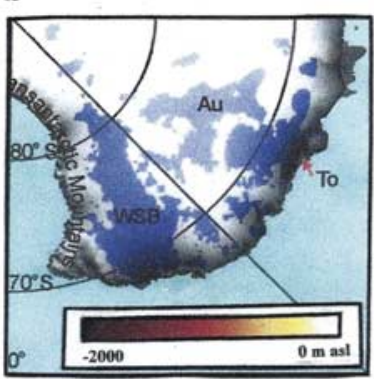

c

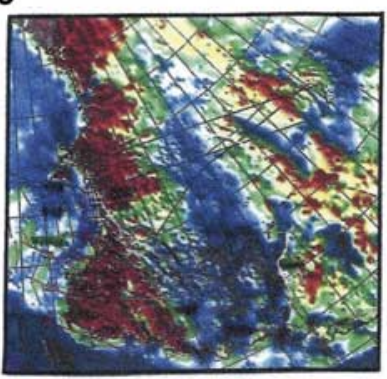

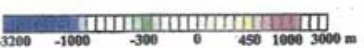

Fig. 3. Recent surveys conducted in East Antarctica now confirm the spatial dimensions, depth and general configuration of the Wilkes Subglacial Basin. a. BEDMAP1 radio-echo sounding (Lythe et al. 2001, Le Brocq et al. 2008). b. Continental ice sheet flow studies (Bamber et al. 2000). c. Airborne survey (Ferraccioli et al. 2009).

subglacial configuration of the WSB (Fig. 3a). This work is supplemented by that of Bamber et al. (2000) (Fig. 3b), as are aeromagnetic surveys of Ferraccioli et al. (2009) (Fig. 3c) that improve and expand upon the geology, topography and configuration of the WSB. This work, now further enhanced by Fretwell et al. (2013) (Fig. 1), also emphasizes the importance of the elevation of the WSB relative to sea level, and the potential of sea level fluctuation and ocean invasion of the WSB lowland (Fig. 4a).

\section{Hypotheses of origin}

The size of the WSB implies that its origin is due to large scale geologic processes operating on a continental or sub-continental scale. The initial hypotheses of origin have focused on lithospheric flexure (ten Brink et al. 1997), the WSB comprising thick continental crust and the 'low' of a lithospheric flexure that contrasts with the TAM as the flexural 'high' driven by extension within the RSR. Coupling of the WSB and the RSR to the central uplift of the TAM, and the differential flexural rigidity of thicker East Antarctica crust and the thinner Ross embayment are interpreted as reflecting contrasting thermal ages and geotherms of the two provinces. The TAM, the boundary between East and West Antarctica, has been described as divergent (ten Brink et al. 1997), with the WSB to the west
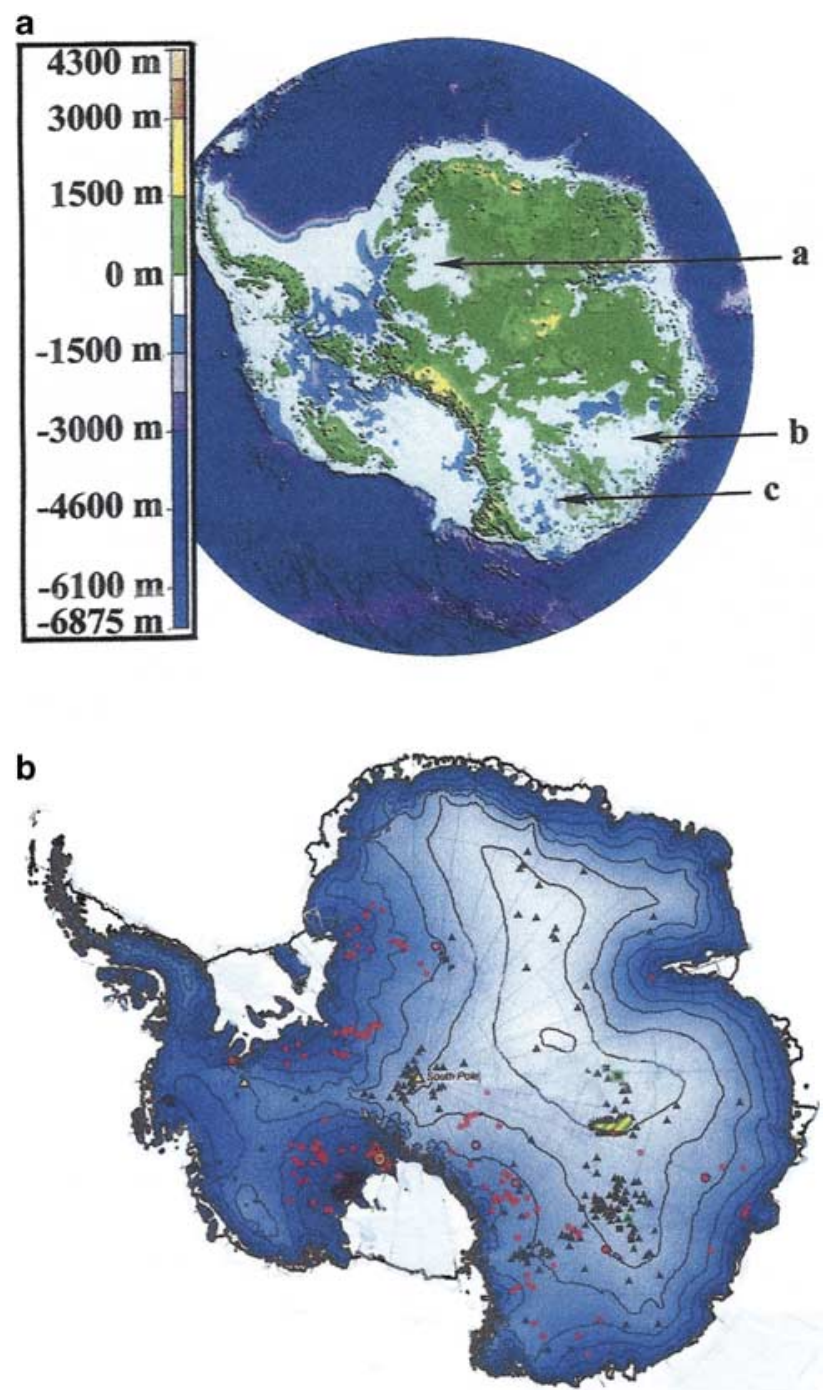

Fig. 4. a. Topography and bathymetry of the Antarctic continent showing relief and elevations above and below sea level in the a) Dronning Maude Land subglacial basin, b) Aurora Subglacial Basin, and c) Wilkes Subglacial Basin (Lythe et al. 2001, Cafarella et al. 2006). b. The fourth inventory of subglacial lakes in Antarctica (courtesy M. Siegert). The red-circle lakes have been identified by ICESat surface uplift events and the black-triangle lakes have been detected by radio-echo sounding, the ice surface contour interval is $500 \mathrm{~m}$ (Wright \& Siegert 2012).

of the TAM depressed $1 \mathrm{~km}$ below sea level and the Victoria Land basin to the east of the TAM as an area of extension in which $4-5 \mathrm{~km}$ of Cenozoic sediments have accumulated. This model, augmented by the isostatic effects of erosion and mass loss combined with thermal uplift of the TAM, is offered in support of hypothetical rifting reminiscent of foreland basins, 'though remaining poorly understood' (ten Brink et al. 1997).

Since these investigations, gravity modelling (Jordan et al. 2013) has revealed East Antarctic crustal thickness to 
be less than that predicted by the flexural model and c. $15 \mathrm{~km}$ less than that of the TAM. Studinger et al. (2004) report a crustal thickness of c. $31 \mathrm{~km}$, and sedimentary infill of less than $1 \mathrm{~km}$ in basins of the WSB, leading to the belief that the WSB contains a former broad back-arc basin and fold-and-thrust belts and craterform topography (Ferraccioli et al. 2009, Weihaupt et al. 2010). The large volumes of Jurassic tholeites imaged in the WSB and intruded and extruded over Beacon sediments, and grabenlike features with up to $1.5 \mathrm{~km}$ sedimentary infill in the central basins suggest a rift setting (Ferraccioli et al. 2009), again instead of the flexural model.

The most recent data, from Jordan et al. (2013), present aeromagnetic and aerogravity data from northern WSB in the vicinity of separation of the East Antarctic craton from south-eastern Australia. These data confirm a crustal thickness of $30-35 \mathrm{~km}$, some $5-10 \mathrm{~km}$ thinner than under the TAM, and some $15 \mathrm{~km}$ thinner than postulated by flexural models for the southern WSB, and support the belief that inherited tectonic structures controlled the location of the WSB. Isostatic anomalies reveal tectonic structures along the eastern and western flanks of the WSB that appear to have controlled the location of the basin, suggesting that the WSB may be imposed on a back-arc region adjacent to the East Antarctic craton, that there may have been Jurassic to Cretaceous lithospheric extension prior to break-up from Australia (Escutia et al. 2005), and that Cenozoic glacial erosion may be a significant factor in thinning the northern Victoria Land crust (Thomson et al. 2013). Gravity and magnetic modelling favour a 'broad extension (of the crust) beneath the enigmatic basin' and suggest further that although the basin may be a 'component of a flexural triad', involving the WSB, the TAM and the RSR, the WSB is neither a flexural depression, a continental rift, nor extended crustal terrain (Armadillo et al. 2007)! While emphasizing the complexity of the WSB, these several investigators conclude that thermal and uplift hypotheses are difficult to reconcile with the aerogravity data, pointing out that a reassessment of existing hypotheses is needed.

Given the enigmatic character of the WSB, and the uncertainty about its origin and geologic history, three alternative hypotheses remain: i) the WSB is a combination of tectonic processes that are not as yet fully understood nor elucidated, ii) the WSB is a consequence of large scale erosional or depositional events, or iii) it is a consequence of both. The evidence to date suggests the latter, that the WSB is the result primarily of tectonic processes and that post-tectonic processes have had a significant impact on the geology and configuration of the basin (Bamber et al. 2000, Jordan et al. 2013). Erosional and depositional processes, acting independently or in concert, have the potential to explain much about the size, shape and subglacial topographic configuration of the WSB. The processes that suggest themselves are glacial and marine erosion and deposition subsequent to tectonism.

\section{Post-tectonic processes}

The 'highly contentious stability' of the continental ice sheet overlying the WSB (Ferraccioli et al. 2009), emphasizes not only its potential for the ice sheet having influenced the configuration of the WSB, but as well as its potential for collapse. Glacial erosion, dynamic and actively down-cutting, operates over comparatively short geological durations. Glacier and continental ice sheet movements have the capacity to substantially erode the subglacial surface (Pattyn 2010) and are always accompanied by deposition. Long-term glacial erosion (normal ice sheet flow) and short-term glacial erosion (ice streams and glacial surge) may be augmented by the presence of water at the base of the ice mass (Rignot et al. 2011). While the exact mechanisms of ice sheet dynamics are not yet known (Rignot et al. 2011), the presence of water plays a crucial role in ice sheet stability (Llubes et al. 2006), and friction at the basal interface of an ice sheet plays a pivotal role in controlling ice dynamics. Hughes (2009) points out that the glacial erosion and evolution of landscapes under the ice occurs only where the bed is not frozen, and basal water production may be a function in part of temperature increase from geothermal heat (Pattyn 2010), the heat of friction, or heat introduced with increased water saturation levels. Siegert et al. (2005), on the basis of radar survey, identifies subglacial lakes and water-saturated basal sediment beneath the East Antarctic ice sheet that favour continental ice sheet movement. Wright \& Siegert (2012) identify 379 such subglacial lakes (Fig. 4b), most of which lie in East Antarctica, and lie prominently in groupings in the WSB. The water-related conditions at the base of the East Antarctic continental ice sheet appear therefore to be abundantly present, and correlate with the onset of enhanced glacial flow (Wright \& Siegert 2012). Similarly, water-saturated basal sediments exist in the WSB, also favouring glacial processes in influencing the morphology of the WSB. Smooth subglacial topography noted in the WSB (Wright \& Siegert 2012) reduces basal friction and promotes rapid ice sheet flow.

The triangular shape of the WSB, the non-equidimensional morphology with non-parallel boundaries, is uncharacteristic of a tectonic origin (Studinger et al. 2004), suggesting that a non-tectonic mechanism is needed to explain the triangular shape of the basin. Because continental ice sheet velocities and ice volumes downstream tend to be much greater than those upstream, downstream erosion tends to be greater than erosion upstream. In particular, the additive volumes of ice accumulating downstream are greater than those upstream, and the downstream swatches of moving ice are wider than those upstream. The anticipated subglacial erosion is therefore coincident with a triangular configuration, with an upstream apex and a downstream base much like the triangular shape of the WSB. Jordan et al. (2013), on the other hand, suggest that both margins of the WSB are structurally 
controlled, and that the triangular shape results from the intersection of these two structures.

While major uncertainties exist about basal conditions, including the temperature field and geothermal heat flow (Pattyn 2010), ice streams in the continental ice sheet are less likely than continental ice sheet advance or recession per se to create significant changes in the large scale configuration of the WSB, or in its subglacial topography. Jamieson et al. (2010) note that interior continental erosion prior to emplacement of the East Antarctic continental ice sheet is likely to have been less that $200 \mathrm{~m}$, much like that of the Laurentian and Scandinavian shields. In contrast, the early East Antarctic continental ice sheet is likely to have been dynamic, with ice flow concentrated along fixed ice streams (Thomson et al. 2013), with consequent selective erosion of the 'ice-hidden' landscape. Erosional downcutting along the continental margins may have been as much as $2.8 \mathrm{~km}$ due to high erosion rates caused by steep thermal gradients in basal ice (Jamieson et al. 2010), and Whitehead \& Clift (2009) note that thickened elevated continental crust is subject to severe erosion. Ice streams may in fact respond to or affect not only the subglacial topography (Truffer \& Echelmeyer 2003), but the overlying ice sheet as well. The development of ice streams within a continental ice sheet often transforms the surface of the ice (Bamber et al. 2000), creating substantial crevassing and large blocks in the continental ice sheet (Truffer \& Echelmayer 2003), which have been noted in the East Antarctic continental ice sheet in near coastal regions (Weihaupt et al. 2012). Capable of creating dramatic change over comparatively short intervals (Bamber et al. 2000), ice streams may represent a hundred-fold increase in velocity (Jezek 2002), with the result that significant subglacial topographic effects are likely (Bianchi et al. 2003). Not only are significant topographic reconfigurations possible, but Earth's continental crust may be significantly thinned by erosion (Whitehead \& Clift 2009), depending upon the rate and mass of glacier or ice sheet movement. The presence of ice streams in the WSB continental ice sheet, in the form of the Mertz and Ninnis glaciers, is another example of nontectonic processes in the WSB that may have influenced its morphology. These observations make apparent the potential influence of climatic and sea level variations that may ultimately have impacted the configuration of the WSB.

\section{Climate and sea level change}

Subglacial topographic smoothness is generally greater when the bed is below sea level (Siegert et al. 2005), as in the case of much of the WSB. This basin is the only extensive subglacial region in East Antarctica that descends below $-500 \mathrm{~m}$ elevation (Fig. 4a) (Fretwell et al. 2013), a consequence of the processes that formed the WSB and of the isostatic adjustment that has accompanied lithospheric depression due to the load of the continental ice sheet.
Should all or a portion of the East Antarctic continental ice sheet collapse, the ocean would invade the lowland, although isostatic rebound would eventually expel some portion of the sea from the WSB. Flooding from the Southern Ocean would be accompanied by marine erosion and deposition, and the WSB somewhat reconfigured. It should be noted that such sediments may be draped over features created by earlier tectonic events, thus modifying pre-existing subglacial topography.

WSB topography is 'extremely smooth' (Siegert 2005) compared to adjacent regions, also implying a role for sea level rise and marine deposition. The record of global sea level variations is coincident with the record of ice sheet growth and decline (Miller et al. 2011), further substantiating the likely influence of marine processes on the WSB. Global sea level fluctuations, responses to variations in continental ice sheet volumes, are therefore responses also to global climatic change.

Global climatic change, to a first approximation, is a function of solar activity and Earth's orbital parameters, i.e. orbital eccentricity, obliquity and precession. Each of these fundamental drivers of climate change affects the distribution and amount of incident solar radiation, enabling predictable pacing of the planet's climate in geological time, including potential past glacial activity and sea level fluctuations. The effects of plate tectonics are superimposed upon orbitally-induced variations, and include the effects of continental geography, oceanic gateways, bathymetry and volcanic greenhouse gas concentrations. These give rise to climatic episodes on million-year timescales, collectively giving rise to extremes of expansive warmth with ice-free poles and to extremes of cold with massive ice sheets at the poles (Zachos et al. 2001, Mayewski et al. 2006), including 'extremes in Antarctic ice-volume and temperature' (Zachos et al. 1997). Considering that the total removal of the Antarctic continental ice sheet is equivalent to a $57 \mathrm{~m}$ rise in sea level, and the return of the continental ice sheet equivalent to similar declines in sea level after ocean incursion, recession and isostatic response, the timing of glacial events is critical to unravelling the times of both ice sheet and marine modification of the WSB.

Whereas the Pleistocene and Holocene have seen some of the lowest sea levels in the Phanerozoic, global sea level increases of some $100 \mathrm{~m}$ or more occurred before the ice sheets developed, with specific increases of $250 \mathrm{~m}$ (53 Ma), $200 \mathrm{~m}$ (40 Ma) and $65 \mathrm{~m}$ (33 Ma). Significant global climatic cooling and the onset of glaciation in East Antarctica occurred in late Eocene (Escutia et al. 2005). The first significant permanent ice sheet appeared, therefore, c. $34 \mathrm{Ma}$. The latter part of the Oligocene then saw a warming trend that reduced the extent of the Antarctic continental ice sheet and increased global sea level between $27 \mathrm{Ma}$ and $26 \mathrm{Ma}$, i.e. $45 \mathrm{~m}$ (26 Ma), $45 \mathrm{~m} \mathrm{(20} \mathrm{Ma)}$ and $25 \mathrm{~m}(15 \mathrm{Ma})$, peaking in a mid-Miocene climatic optimum between $17 \mathrm{Ma}$ and $15 \mathrm{Ma}$. This was followed in 
mid-Miocene (14-10 Ma) by a transition from a dynamic ice sheet regime to one of oscillatory ice sheets (Escutia et al. 2005), then by a gradual cooling and re-establishment of a major Antarctic ice sheet by $10 \mathrm{Ma}$ and a consequent decrease in global sea level, and by sea level increases of $45 \mathrm{~m} \mathrm{(9Ma)}$ and $50 \mathrm{~m}$ (6 Ma) (Mosbrugger et al. 2005, Miller et al. 2011). This latter ice sheet persisted until early Pliocene and the appearance of a mild warming trend 3.2 Ma.

At least thirty continental ice sheet expansions to the coast and retreats to East Antarctica's subglacial highlands occurred after $34 \mathrm{Ma}$. Since $34 \mathrm{Ma}$, shorter intervals of major ice sheet growth and decline were superimposed upon these longer term trends at $35.0-31.0 \mathrm{Ma}, 24.5-20.5 \mathrm{Ma}$, $16.5-12.5 \mathrm{Ma}$ and $4.0-0.0 \mathrm{Ma}$, recording the frequency of alternating erosional and depositional events in the WSB, and the presence at times of 'extremely dynamic' ice sheets (Zachos et al. 2001, Escutia et al. 2005). Likely modification of the tectonically-structured basin is, therefore, abundantly evident in the late Cenozoic climatic, glacial and sea level record.

These observations are also consistent with WSB ice sheet history derived from Earth's orbital geometry (Zachos et al. 2001, Huybers 2009), from the record revealed by continental margin sediments (Escutia et al. 2005), oxygen isotope analyses (Mosbrugger et al. 2005), atmospheric carbon dioxide concentrations (Lüthi et al. 2008, Schmitt et al. 2012), atmospheric temperature (Escutia et al. 2005), palaeoclimate (Zachos et al. 2001, Tripati et al. 2009), ice sheet advance and decline, and sea level fluctuations (Miller et al. 2011). We conclude that the location and fundamental configuration of the basin is a function of tectonic activity, and that post-tectonic processes have had a substantial role in the present configuration of the Wilkes Subglacial Basin.

\section{Acknowledgements}

We wish to thank colleagues who were members of the Victoria Land Traverse team, and who helped assure the success of that exploration. Among these are Alfred W. Stuart, William M. Smith, Arnold J. Heine, Louis Roberts, Alfred Taylor, Thomas Baldwin and Warren Jackman. We thank in particular readers of the paper, A. Vaughan, T. Hughes and T. Jordan who made very helpful suggestions, and who demonstrated a very professional and sincere willingness to be of assistance in the publication of this paper. We also wish to thank colleagues who kindly provided material for the figures, J. Bamber, L. Cafarella, H. Corr, F. Ferraccioli, P. Fretwell, A. Le Brocq and M. Siegert. Finally, we wish to thank the United States National Science Foundation for support of the original field investigations, the University of Colorado Denver, Delft University of Technology and the Laboratoire de Glaciologie et Géophysique de l'Environnement for resource and administrative support. We also thank the reviewers for their comments on the manuscript.

\section{References}

Armadillo, E., Bozzo, E., Caneva, G., Manzella, A. \& Ranieri, G. 2007. Imaging deep and shallow structures by electromagnetic soundings moving from the Transantarctic Mountains to the Wilkes Subglacial Basin. Terra Antarctica Reports, 13, 65-74.

Bamber, J.L., Vaughan, D.G. \& Joughin, I. 2000. Widespread complex flow in the interior of the Antarctic ice sheet. Science, 287, $1248-1250$.

Bianchi, C., Cafarella, L., De Michelis, P., Forieri, A., Frezzotti, M., Tabacco, I.E. \& Zirizzotti, A. 2003. Radio echo sounding (RES) investigations at Talos Dome (East Antarctica): bedrock topography and ice thickness. Annals of Geophysics, 46, 1265-1270.

Cafarella, L., Urbini, S., Bianchi, C., Zirizzotti, A., Tabacco, I.E. \& Forieri, A. 2006. Five subglacial lakes and one of Antarctica's thickest ice covers newly determined by radio echo sounding over the Vostok Dome C region. Polar Research, 25, 69-73.

Escutia, C., De Santis, L., Donda, F., Dunbar, R.B., Cooper, A.K., Brancolini, G. \& EitrReim, S.L. 2005. Cenozoic ice sheet history from East Antarctic Wilkes Land continental margin sediments. Global and Planetary Change, 45, 51-81.

Ferraccioli, F., Armadillo, E., Jordan, T., Bozzo, E. \& Corr, H. 2009. Aeromagnetic exploration over the East Antarctic Ice Sheet: a new view of the Wilkes Subglacial Basin. Tectonophysics, 478, $62-77$

Fretwell, P., Pritchard, H.D. \&, Vaughan, D.G., et al. 2013. BEDMAP2: improved ice bed, surface and thickness datasets for Antarctica. Cryosphere, 7, 375-393.

Hughes, T. 2009. Variations of ice bed coupling beneath and beyond ice streams: the force balance. Journal of Geophysical Research - Solid Earth, 114, 10.1029/2009JB006426.

HuYBers, P. 2009. Antarctica's orbital beat. Science, 325, 1085-1086.

Jamieson, S.S.R., Sugden, D.E. \& Hulton, N.R.J. 2010. The evolution of the subglacial landscape of Antarctica. Earth and Planetary Science Letters, 293, 1-27.

JeZeK, K.C. 2002. RADARSAT-1 Antarctic mapping project: changedetection and surface velocity campaign. Annals of Glaciology, 34, 263-268.

Jordan, T.A., Ferraccioli, F., Armadillo, E. \& Bozzo, E. 2013. Crustal architecture of the Wilkes Subglacial Basin in East Antarctica, as revealed from airborne gravity data. Tectonophysics, 585, 196-206.

Karner, G.D., Studinger, M. \& Bell, R.E. 2005. Gravity anomalies of sedimentary basins and their mechanical implications: application to the Ross Sea basins, West Antarctica. Earth and Planetary Science Letters, 235, 577-596.

Le Brocq, A.M., Hubbard, A., Bentley, M.J. \& Bamber, J.L. 2008. Subglacial topography inferred from ice surface terrain analysis reveals a large un-surveyed basin below sea level in East Antarctica. Geophysical Research Letters, 35, 10.1029/2008GL034728.

Llubes, M., Lanseau, C. \& Remy, F. 2006. Relations between basal condition, subglacial hydrological networks and geothermal flux in Antarctica. Earth and Planetary Science Letters, 241, 655-662.

Lorius, C., Merlivat, L., Jouzel, J. \& Pourchet, M. 1979. 30,000-year isotope climatic record from Antarctic ice. Nature, 280, 644-648.

Lorius, C., Jouzel, J., Raynaud, D., Hansen, J. \& LeTreut, H. 1990. The ice-core record: climate sensitivity and future greenhouse warming. Nature, 347, 139-145.

Lüthi, D., Le Floch, M., Bereiter, B., Blunier, T., Barnola, J.M., Siegenthaler, U., Raynaud, D., Jouzel, J., Fischer, H., Kawamura, K. \& STOCKeR, T.F. 2008. High-resolution carbon dioxide concentration record 650,000-800,000 years before present. Nature, 453, 379-382. 
Lythe, M.B., Vaughan, D.G. \& The Bedmap Consortium. 2001. BEDMAP: a new ice thickness and subglacial topographic model of Antarctica. Journal of Geophysical Research - Solid Earth, 106, $11335-11351$.

Mayewski, P.A., MaAsch, K.A., Yan, Y.P., Kang, S.C., MeYerson, E.A., Sneed, S.B., Kaspari, S.D., Dixon, D.A., Osterberg, E.C., Morgan, V.I., van OMMEN, T. \& CURRAN, M.A.J. 2006. Solar forcing of the polar atmosphere. Annals of Glaciology, 41, 147-154.

Miller, K.G., Mountain, G.S., Wright, J.D. \& Browning, J.V. 2011. A 180-million-year record of sea level and ice volume variations from continental margin and deep-sea isotopic records. Oceanography, 24, $40-53$.

Mosbrugger, V., Utescher, T. \& Dilcher, D.L. 2005. Cenozoic continental climate evolution of Central Europe. Proceedings of the National Academy of Sciences of the United States of America, 102, 14964-14969.

Pattyn, F. 2010. Antarctic subglacial conditions inferred from a hybrid ice sheet/ice stream model. Earth and Planetary Science Letters, 295, 451-461.

Rignot, E., Mouginot, J. \& Scheuchl, B. 2011. Ice flow of the Antarctic ice sheet. Science, 333, 1427-1430.

Schmitt, J., Schneider, R., Elsig, J., Leuenberger, D., Lourantou, A., Chappellaz, J., Köhler, P., Joos, F., Stocker, T.F., Leuenberger, M. \& Fischer, H. 2012. Carbon isotope constraints on the deglacial $\mathrm{CO}_{2}$ rise from ice cores. Science, 336, 711-714.

Siegert, M.J., Taylor, J. \& Payne, A.J. 2005. Spectral roughness of subglacial topography and implications for former ice-sheet dynamics in East Antarctica. Global and Planetary Change, 45, 249-263.

Studinger, M., Bell, R.E., Buck, W.R., Karner, G.D. \& Blankenship, D.D. 2004. Sub-ice geology inland of the Transantarctic Mountains in light of new aerogeophysical data. Earth and Planetary Science Letters, 220, 391-408.
Ten Brink, U.S., Hackney, R.I., Bannister, S., Stern, T.A. \& Makovsky, Y. 1997. Uplift of the Transantarctic Mountains and the bedrock beneath the East Antarctic ice sheet. Journal of Geophysical Research - Solid Earth, 102, 27 603-27 621.

Thomson, S.N., Reiners, P.W., Hemming, S.R. \& Gehrels, G.E. 2013. The contribution of glacial erosion to shaping the hidden landscape of East Antarctica. Nature Geoscience, 6, 203-207.

Tripati, A.K., Roberts, C.D. \& Eagle, R.A. 2009. Coupling of $\mathrm{CO}_{2}$ and ice sheet stability over major climate transitions of the last 20 million years. Science, 326, 1394-1397.

Truffer, M. \& Echelmeyer, K.A. 2003. Of isbrae and ice streams. Annals of Glaciology, 36, 66-72.

Weinaupt, J.G. 1961. Geophysical studies in Victoria Land, Antarctica. Madison, WI: University of Wisconsin Press, Geophysical and Polar Research Center, 123 pp.

Weihaupt, J.G., Rice, A. \& van der Hoeven, F.G. 2010. Gravity anomalies of the Antarctic lithosphere. Lithosphere, 2, 454-461.

Weihaupt, J.G., Stuart, A.W., van der Hoeven, F.G., Lorius, C. \& Smith, W.M. 2012. Impossible journey: the story of the Victoria Land Traverse 1959-1960, Antarctica. Boulder, CO: Geological Society of America, $136 \mathrm{pp}$.

Whitehead, J.A. \& Clift, P.D. 2009. Continent elevation, mountains, and erosion: freeboard implications. Journal of Geophysical Research Solid Earth, 114, 10.1029/2008JB006176.

Wright, A. \& Siegert, M. 2012. A fourth inventory of Antarctic subglacial lakes. Antarctic Science, 24, 659-664.

Zachos, J.C., Flower, B.P. \& Paul, H. 1997. Orbitally paced climate oscillations across the Oligocene/Miocene boundary. Nature, 388, 567-570.

Zachos, J., Pagani, M., Sloan, L., Thomas, E. \& Billups, K. 2001. Trends, rhythms, and aberrations in global climate 65 Ma to present. Science, 292, 686-693. 